\title{
Vitrification of Simulated Radioactive Rocky Flats Plutonium Containing Ash Residue with a Stir Melter System
}

by

J. C. Marra

Westinghouse Savannah River Company

Savannah River Site

Aiken, South Carolina 29808

K R. Kormanyos

Stir-Melter, Inc.

T. J. Overcamp

Clemson Environmental Systems Engineering

\section{DOE Contract No. DE-AC09-89SR18035}

This paper was prepared in connection with work done under the above contract number with the U.S. Department of Energy. By acceptance of this paper, the publisher and/or recipient acknowledges the U.S. Government's right to retain a nonexclusive, royalty-free license in and to any copyright covering this paper, along with the right to reproduce and to authorize others to reproduce all or part of the copyrighted paper. 


\section{DISCLAIMER}

Portions of this document may be illegible in electronic image products. Images are produced from the best available original document. 


\section{DISCLAIMER}

This report was prepared as an account of work sponsored by an agency of the United States Government. Neither the United States Government nor any agency thereof, nor any of their employees, makes any warranty, express or implied, or assumes any legal liability or responsibility for the accuracy, completeness, or usefulness of any information, apparatus, product, or process disclosed, or represents that its use would not infringe privately owned rights. Reference herein to any specific commercial product, process, or service by trade name, trademark, manufacturer, or otherwise does not necessarily constitute or imply its endorsement, recommendation, or favoring by the United States Government or any agency thereof. The views and opinions of authors expressed herein do not necessarily state or reflect those of the United States Government or any agency thereof.

This report has been reproduced directly from the best available copy.

Available to DOE and DOE contractors from the Office of Scientific and Technical Information, P.O. Box 62, Oak Ridge, TN 37831; prices available from (615) 576-8401.

Available to the public from the National Technical Information Service, U.S. Department of Commerce; 5285 Port Royal Road, Springfield, VA 22161. 


\title{
VITRIFICATION OF SIMULATED RADIOACTIVE ROCKY FLATS PLUTONIUM CONTAINING ASH RESIDUE WITH A STIR-MELTER SYSTEM
}

Kenneth R. Kormanyos, Stir-Melter, Inc. James C. Marra, Westinghouse Savannah River Co.

Thomas J. Overcamp, Clemson Environmental Systems Engineering

\begin{abstract}
A demonstration trial has been completed in which a simulated Rocky Flats ash consisting of an industrial fly-ash material doped with cerium oxide was vitrified in an alloy tank Stir-Melter ${ }^{\mathrm{TM}}$ System. The cerium oxide served as a substitute for plutonium oxide present in the actual Rocky Flats residue stream. The glass developed falls within the $\mathrm{SiO}_{2}+\mathrm{Al}_{2} \mathrm{O}_{3} / \Sigma$ Alkali $/ \mathrm{B}_{2} \mathrm{O}_{3}$ system. The glass batch contained approximately $40 \mathrm{wt} \%$ of ash, the ash was modified to contain $\sim 5 \mathrm{wt}$ $\% \mathrm{CeO}_{2}$ to simulate plutonium chemistry in the glass. The ash simulant was mixed with water and fed to the Stir-Melter as a slurry with a $60 \mathrm{wt} \%$ water to $40 \mathrm{wt} \%$ solids ratio. Glass melting temperature was maintained at approximately $1050^{\circ} \mathrm{C}$ during the melting trials. Melting rates as functions of impeller speed and slurry feed rate were determined. An optimal melting rate was established through a series of evolutionary variations of the control variables' settings. The optimal melting rate condition was used for a continuous six hour steady state run of the vitrification system. Glass mass flow rates out of the melter were measured and correlated with the slurry feed mass flow. Melter off-gas was sampled for particulate and volatile species over a period of four hours during the steady state run. Glass composition and durability studies were run on samples collected during the steady state run.
\end{abstract}

\section{INTRODUCTION}

A significant need exists to develop viable methods of immobilizing radioactive residues which contain quantities of plutonium oxide. Vitrification of the residues into a stable leach resistant glass provides a very durable method of immobilization. A team effort incorporating the expertise of three groups has successfully demonstrated the manner in which a vitrification program can be established through surrogate waste glass development, vitrification system operation, and technical analyses of the demonstrated process output streams.

\section{VITRIFICATION DEMONSTRATION TEAM}

Three independent groups teamed together to complete the vitrification demonstration. The team members were Stir-Melter, Inc., Westinghouse Savannah River Co., and Clemson Environmental 
Systems Engineering. Stir-Melter, Inc. provided the operating prototype vitrification system and project coordination, Westinghouse Savannah River Co. identified the simulated "waste stream" and developed the waste glass composition, and Clemson Environmental Systems Engineering supplied the blended dry "waste stream" demonstration batch materials and directed the demonstration vitrification process off-gas analysis.

\section{SIMULATED "WASTE STREAM"}

An industrial fly-ash material was identified as being chemically and physically similar to the ash held at DOE-Rocky Flats less the radioactive plutonium oxide component. The oxide components of the industrial fly-ash are shown in Table I as the WASTE OXIDE combined with the addition of the required $\mathrm{CeO}_{2}$ content to form the simulated "waste oxide" composition. A total of $\sim 5 \mathrm{wt} \%$ $\mathrm{CeO}_{2}$ was added to the industrial fly-ash to serve as the plutonium oxide surrogate.

\section{Table I. Oxide Compositions, Components of "Fly-Ash 6" Glass}

\begin{tabular}{|c|c|c|c|}
\hline GLASS ID $=$ & FLY ASH - 6 & & \\
\hline FRIT WT\% & 60 & & \\
\hline WASTE WT $\%$ & 40 & & \\
\hline ELEMENT & FRIT & WASTE & GLASS \\
\hline OXIDE & OXIDE wt $\%$ & OXIDE wt\% & OXIDE wt\% \\
\hline Al/Al2O3 & & 25.72 & 10.28 \\
\hline $\mathrm{B} / \mathrm{B} 2 \mathrm{O} 3$ & 25.00 & & 15.00 \\
\hline $\mathrm{Ca} \mathrm{CaO}$ & & 1.84 & 0.74 \\
\hline \multicolumn{4}{|l|}{$\mathrm{Cr} / \mathrm{Cr} 2 \mathrm{O3}$} \\
\hline \multicolumn{4}{|l|}{ Cs/Cs2O } \\
\hline $\mathrm{Fe} / \mathrm{Fe} 2 \mathrm{O} 3$ & & 12.28 & 4.91 \\
\hline K/K2O & & 1.71 & 0.68 \\
\hline \multicolumn{4}{|l|}{ LíLi2O } \\
\hline $\mathrm{Mg} / \mathrm{MgO}$ & & 0.76 & 0.30 \\
\hline \multicolumn{4}{|l|}{$\mathrm{Mn} / \mathrm{MnO} 2$} \\
\hline Ti/TiO2 & & 1.45 & 0.58 \\
\hline \multicolumn{4}{|l|}{$\mathrm{Na} / \mathrm{NaCl}$} \\
\hline $\mathrm{Ce} / \mathrm{CeO} 2$ & & 4.50 & 1.80 \\
\hline \multicolumn{4}{|l|}{$\mathrm{Na} / \mathrm{Nal}$} \\
\hline $\mathrm{Na} / \mathrm{Na2O}$ & 33.00 & 0.33 & 19.39 \\
\hline P/P205 & & 0.44 & 0.18 \\
\hline S/SO3 & & 1.44 & 0.58 \\
\hline Si/SiO2 & 42.00 & 49.36 & 44.94 \\
\hline Sr/Sro & & 0.18 & 0.07 \\
\hline \multicolumn{4}{|l|}{$\mathrm{Zr} / \mathrm{ZrO} 2$} \\
\hline SUMS & 100.00 & 100.01 & 100.00 \\
\hline
\end{tabular}

\section{WASTE GLASS DEVELOPMENT}

A group of glasses was developed to incorporate the "waste stream" into their compositions. The several compositions developed fell in the $\mathrm{SiO}_{2}+\mathrm{Al}_{2} \mathrm{O}_{3} / \Sigma$ Alkali / $\mathrm{B}_{2} \mathrm{O}_{3}$ system as shown in Figure I. Variations in the level of fly-ash surrogate were made over a $35 \%-50 \%$ wt $\%$ range. PCT tests were run on the glasses of the crucible studies with acceptable results compared to the HLW benchmark environmental assessment glass (EA-glass).

\section{Figure I. Ternary Plot Showing the Developed Waste Glasses}




\section{Figure I. Ternary Plot Showing the Developed Waste Glasses}

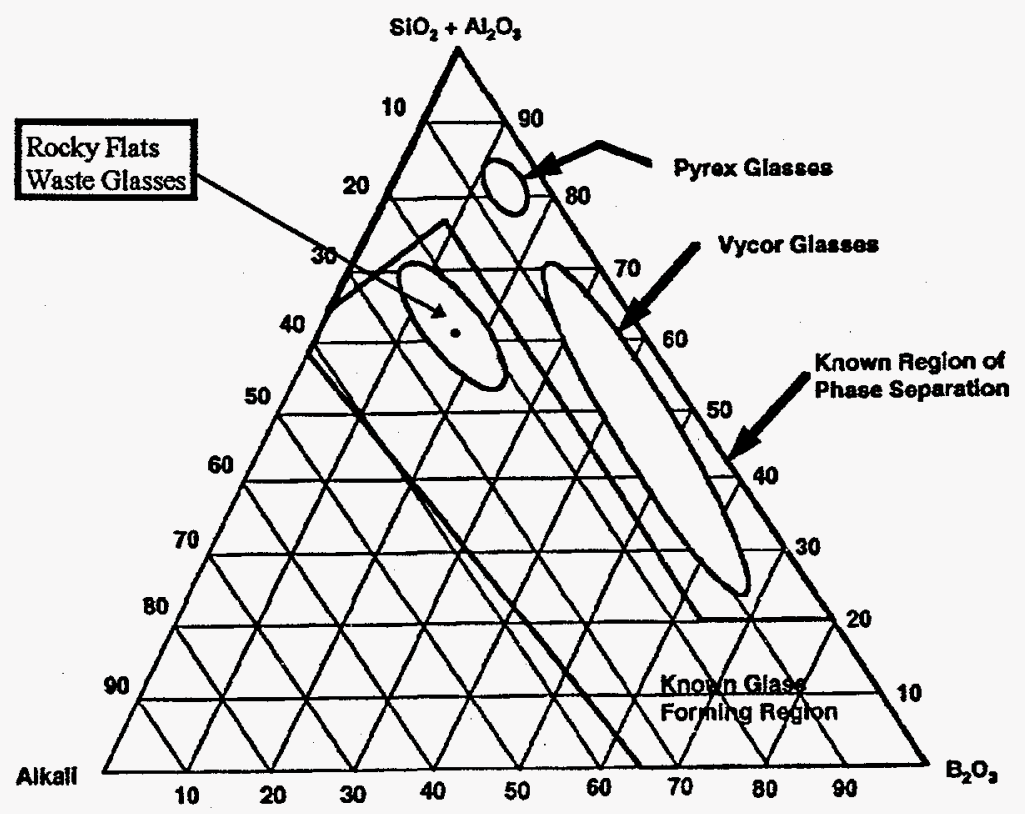

A single glass composition from the crucible study was selected to serve as the material to be evaluated in the vitrification process study; it had an ash loading of $40 \mathrm{wt} \%$ in its batch composition. The selected glass is shown in Table I as "FLY ASH - 6," with its oxide composition listed along with the frit oxide and waste oxide components blended to obtain the glass. The PCT test results for "FLY ASH - 6" crucible samples are shown in Table II. Toxicity Characteristic Leaching Procedure (TCLP) tests have shown that leaching of hazardous metals in the glasses developed are below regulatory limits.

\section{Table II. Comparative PCT Test Results for Crucible Samples}

\begin{tabular}{|cccc|}
\hline \multicolumn{4}{|c|}{ PCT Releases, Surrogate Rocky Flats Ash Glasses } \\
Glass & Normalized Release $(\mathrm{g} / \mathrm{L})$ & $\mathrm{B}$ \\
& $\mathrm{Na}$ & $\mathrm{Si}$ & \\
Comp. 2 & 2.07 & 0.23 & 2.89 \\
Comp. 1 & 1.06 & 0.28 & 1.06 \\
& & & \\
EA Glass & 13.35 & 3.92 & 16.70 \\
\hline
\end{tabular}

Approximately $200 \mathrm{~kg}\left(-440 \mathrm{lb}_{\mathrm{m}}\right)$ dry batch material was prepared for the demonstration vitrification run. The industrial fly-ash was blended with cerium carbonate to provide the equivalent of $\sim 5 \mathrm{wt} \%$ cerium oxide which served as the surrogate for plutonium oxide in the Rocky Flats ash. The fly-ash blend provided $40 \mathrm{wt} \%$ of the total waste glass composition. The 
remaining components of the batch, borax, soda ash, and silica were blended with the fly-ash to develop the glass described in Table I as the GLASS OXIDE.

\section{STIR-MELTER VITRIFICATION SYSTEM}

Stir-Melter, Inc. lab facility's alloy A-0.5 joule-heated, double wall, melter system ${ }^{1}$ was used for the vitrification demonstration. The melter was connected to an operating off-gas collection system which consisted of a water spray packed cooling column, 65\% ASHRAE filter, 95\% ASHRAE bag filter, and $99.9 \%$ HEPA filter. A 190 liter (50 gallon) slurry maintenance and pumping system was used to mix and deliver the demonstration feed material.

The Stir-Melter System had a $0.05 \mathrm{~m}^{2}\left(0.5 \mathrm{ft}^{2}\right)$ melter area Inconel 601 melting vessel which had an approximate constant working volume of $0.01 \mathrm{~m}^{3}\left(0.36 \mathrm{ft}^{3}\right)$ with a bottom fed overflow U-tube delivery spout for the glass product. An Inconel 690 impeller served as the AC electrode with the vessel maintained at ground potential. Impeller speed was controllable from $0-500 \mathrm{rpm}$ and the impeller height could be controlled within the working volume of the vessel. Joule-heating power available to the unit was $10 \mathrm{KVA}$, auxiliary resistance heating power was $3 \mathrm{KVA}$, and impeller drive power was $1 \mathrm{KVA}$. The melter system operated at a temperature of $1050^{\circ} \mathrm{C}$. The melter had a slurry feed port, a dry material feed port, an off-gas port, and a video/photo port available for process operation and monitoring.

\section{VITRIFICATION DEMONSTRATION PREPARATION}

Dry batch material received from Clemson Environmental Systems Engineering was charged into the drained, hot, Stir-Melter system to provide the initial glass volume required for the start of the joule-heating process. Sufficient dry batch was introduced to the melter to achieve its fixed constant working volume of glass. The initial batch charge was melted with heat supplied by the auxiliary heaters.

A water based slurry of the supplied batch was prepared. The slurry was mixed to provide a 60 $\mathrm{wt} \%$ water to $40 \mathrm{wt} \%$ solids ratio for feeding directly into the operating Stir-Melter system. A water cooled slurry feed tube served to introduce the slurry into the melter. A calibrated peristaltic pump controlled the slurry mass flow feed rate to the melter.

The details of the off-gas sampling requirements were specified by Clemson Environmental Systems Engineering. An outside vendor was contracted to provide the off-gas sampling and analysis service during the continuous run portion of the demonstration.

\section{VITRIFICATION RATE OPTIMIZATION}

A designed experimental matrix of slurry feed rate and impeller speed provided the basis for investigation of the optimal slurry feed rate to the Stir-Melter system. Each set of operating conditions was maintained for 30 minutes, which was sufficient time for the verification of process mass flow equilibrium based upon slurry input, solids content, ignition loss, and glass output. Following the completion of the experimental matrix design, a series of evolutionary feed rate and impeller settings were investigated to determine the optimal settings to yield the 
maximum glass output rate for the steady state vitrification demonstration. The results of the study showed optimal vitrification of the "waste stream" for the following conditions.

- Slurry feed rate of $6.25 \mathrm{~kg} / \mathrm{hr}$

- Melter temperature of $1050^{\circ} \mathrm{C}$

- Impeller speed of $350 \mathrm{rpm}$

- Glass output rate of $2.5 \mathrm{~kg} / \mathrm{hr}$

\section{CONTINUOUS VITRIFICATION DEMONSTRATION}

A six (6) hour continuous vitrification demonstration run was completed. The Stir-Melter system was set to control its operational set points at a melting temperature of $1050^{\circ} \mathrm{C}$ and an impeller speed of $350 \mathrm{rpm}$. The slurry feed system was set for an input rate of $6.25 \mathrm{~kg} / \mathrm{hr}$. The off-gas system was set to maintain a -0.025 kiloPascal $(-0.1$ in.wc.) head space pressure above the melt surface within the alloy tank to assure extraction of the generated steam and off-gas species from the process. The slurry feed composition for the demonstration is shown in Table III as

SL-FEED CA-1, -2. The dry batch materials used to form the slurry are shown in Table III as DR-FEED CA-1, -2. The solids content of the slurry were analyzed and are shown in Table IV.

Table III. Feed Material Analyses

Feed Composition (wt \%)

\begin{tabular}{|c|c|c|c|c|c|}
\hline Oxide & Target & $\begin{array}{r}\text { SL-FEED } \\
\text { CA-1 }\end{array}$ & $\begin{array}{r}\text { SL-FEED } \\
\text { CA-2 }\end{array}$ & $\begin{array}{r}\text { DR-FEED } \\
\text { CA-1 }\end{array}$ & $\begin{array}{r}\text { DR-FEED } \\
\text { CA-2 }\end{array}$ \\
\hline $\mathrm{SiO} 2$ & 44.94 & 41.18 & 40.95 & 39.03 & 40.19 \\
\hline $\mathrm{Na} 2 \mathrm{O}$ & 19.93 & 19.43 & 17.14 & 16.48 & 17.03 \\
\hline Al2O3 & 10.29 & 8.11 & 8.17 & 8.40 & 8.42 \\
\hline $\mathrm{B} 2 \mathrm{O} 3$ & 15.00 & 10.46 & 9.44 & 9.02 & 7.62 \\
\hline $\mathrm{CeO} 2$ & 1.80 & 1.11 & 0.98 & 0.80 & 0.68 \\
\hline $\mathrm{CaO}$ & 0.74 & 0.69 & 0.73 & 0.60 & 0.63 \\
\hline $\mathrm{Fe} 2 \mathrm{O} 3$ & 4.91 & 3.66 & 7.69 & 4.01 & 4.17 \\
\hline $\mathrm{K} 20$ & 0.68 & 0.59 & 0.65 & 0.61 & 0.57 \\
\hline TiO2 & 0.58 & 0.49 & 0.50 & 0.51 & 0.54 \\
\hline P205 & 0.18 & 0.20 & 0.24 & 0.23 & 0.26 \\
\hline $\mathrm{SrO}_{2}$ & 0.07 & 0.06 & 0.06 & 0.06 & 0.06 \\
\hline $\mathrm{Cr} 2 \mathrm{O} 3$ & 0.00 & 0.12 & 0.05 & 0.02 & 0.20 \\
\hline $\mathrm{Li} 2 \mathrm{O}$ & 0.00 & 0.03 & 0.04 & 0.02 & 0.03 \\
\hline $\mathrm{MgO}$ & 0.30 & 0.25 & 0.26 & 0.26 & 0.26 \\
\hline $\mathrm{SO} 3$ & 0.58 & $\mathrm{n} / \mathrm{a}$ & $n / a$ & $\mathrm{n} / \mathrm{a}$ & na \\
\hline TOTAL & 100.00 & 86.38 & 86.90 & 80.05 & 80.66 \\
\hline
\end{tabular}

Low silica, alumina and ceria numbers may be attributable to difficulties in dissolving the ash feed (l.e. silica, cerium carbonate, etc) when analyzing. 
Table IV. Solids Loading in Slurry Feed Samples

\begin{tabular}{|cccc|}
\hline \multicolumn{4}{|c|}{ Microwave Drying Results } \\
Wt \% Solids & & \\
Sample & Test 1 & $\frac{\text { Test 2 }}{41.48}$ & $\frac{\text { Test 3 }}{41.72}$ \\
SOL-1 & 40.68 & 40.06 & 39.87 \\
SOL-2 & 39.58 & 40.8 \\
\hline
\end{tabular}

Glass output mass flow samples were taken at 15 minute intervals throughout the demonstration period. The glass samples collected also served as analysis specimens for chemical analysis, PCT, crystallinity and homogeneity tests. One hour into the run after assured steady state operation had been established, a four hour period of operation for off-gas sampling was maintained. The samples were collected from the off-gas line approximately 1.5 meters from the melt surface. Additionally, stack samples were taken from the off-gas system at a location downstream of the HEPA filter at the building exhaust stack. The vitrification process continued an additional hour following the off-gas sampling period to complete the six hour demonstration. The dynamics of the melt surface, slurry introduction, impeller draw-down of the slurry, and offgas generation from within the melt were documented with video recordings and still photos during the demonstration.

\section{ANALYSES RESULTS OF COLLECTED DEMONSTRATION GLASSES}

The glass samples collected during the course of the demonstration were submitted for analyses by WSRC laboratories. A complete set of analyses was requested to verify the glass chemical composition, crystallinity, homogeneity and PCT qualities.

\section{PCT ANALYSES OF DEMONSTRATION GLASSES}

Seven day PCT tests were completed on the demonstration glasses collected during the test run. Results of the tests are shown in Table V. for two sampling periods RF-2, -4 and are compared to the "EA Glass."

Table V. Comparative PCT Test Results for Demonstration Samples

\begin{tabular}{|lccc|}
\hline \multicolumn{3}{l}{ PCT Releases Surrogate Rocky Flats Ash } \\
Demonstration Glasses \\
\hline \multicolumn{5}{c}{ Normalized Release $(g /)$} \\
Glass & $\underline{\mathrm{Na}}$ & $\underline{\mathrm{Si}}$ & $\underline{\mathrm{B}}$ \\
$\mathrm{RF}-2$ & 3.48 & 0.48 & 2.75 \\
$\mathrm{RF}-4$ & 3.73 & 0.48 & 2.96 \\
EA Glass & 13.35 & 3.92 & 16.70 \\
\hline
\end{tabular}

\section{XRD ANALYSES}

X-Ray Diffraction analyses of the samples collected during the demonstration run show that the output of the melter was all amorphous material. The action of the impeller in combination with 
the melting temperature of $1050^{\circ} \mathrm{C}$ provided a well melted and blended output glass from a slurry feed of the batch blend. The results are shown in Figure II.

\section{Figure II. Typical X-Ray Diffraction Analyses of Sampled Demonstration Glass}

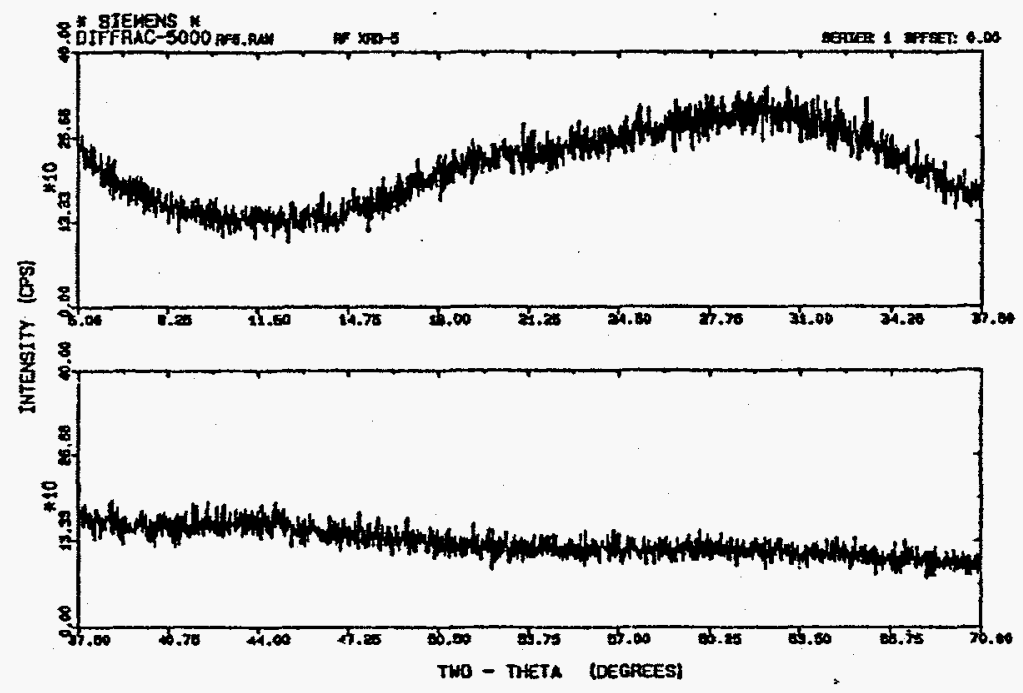

\section{GLASS CHEMICAL ANALYSES}

Chemical analyses of the samples collected during the demonstration run were completed. Five (5) samples of glass output taken during the demonstration yielded a set of results which show close correspondence with the target glass composition. The variation of composition generated during the run was quite small as seen by the several sets of analyses results. The results are shown in Table VI, as CA-1, $-2, \ldots,-5$.

Table VI. Chemical Analyses of Collected Demonstration Process Glass Samples

\begin{tabular}{|c|c|c|c|c|c|c|c|c|}
\hline Oxide & Target & $\begin{array}{r}\text { AVG. CA-1 } \\
\text { to CA-5 }\end{array}$ & STDEV & CA-1 & CA-2 & $\mathrm{CA}_{-3}$ & $C A-4$ & CA- 6 \\
\hline SiO2 & 44.94 & 47.43 & 0.23 & 47.57 & 47.19 & 47.17 & 47.57 & 47.63 \\
\hline $\mathrm{Na2O}$ & 19.93 & 19.48 & 1.59 & 22.04 & 19.98 & 18.30 & 18.75 & 18.31 \\
\hline $\mathrm{Al} 2 \mathrm{O} 3$ & 10.29 & 8.52 & 0.51 & 9.03 & 8.21 & 9.10 & 8.00 & 8.28 \\
\hline B2O3 & 15.00 & 12.56 & 0.06 & 12.66 & 12.49 & 12.55 & 12.56 & 12.54 \\
\hline $\mathrm{CeO} 2$ & 1.80 & 1.35 & 0.18 & 1.47 & 1.30 & 1.61 & 1.22 & 1.17 \\
\hline $\mathrm{CaO}$ & 0.74 & 0.76 & 0.05 & 0.72 & 0.72 & 0.76 & 0.78 & 0.83 \\
\hline $\mathrm{Fe} 2 \mathrm{O} 3$ & 4.91 & 4.61 & 0.22 & 4.93 & 4.60 & 4.70 & 4.39 & 4.44 \\
\hline K2O & 0.68 & 0.80 & 0.02 & 0.78 & 0.84 & 0.79 & 0.81 & 0.79 \\
\hline TIOZ2 & 0.58 & 0.57 & 0.01 & 0.58 & 0.56 & 0.57 & 0.56 & 0.57 \\
\hline P2O5 & 0.18 & 0.09 & 0.01 & 0.10 & 0.10 & 0.09 & 0.09 & 0.08 \\
\hline Sro & 0.07 & 0.06 & 0.00 & 0.06 & 0.06 & 0.06 & 0.06 & 0.06 \\
\hline $\mathrm{Cr}_{2} \mathrm{O} 3$ & 0.00 & 0.21 & 0.02 & 0.24 & 0.22 & 0.21 & 0.20 & 0.19 \\
\hline Li2O & 0.00 & 0.22 & 0.03 & 0.26 & 0.23 & 0.22 & 0.20 & 0.18 \\
\hline $\mathrm{MgO}$ & 0.30 & 0.40 & 0.01 & 0.42 & 0.39 & 0.39 & 0.39 & 0.39 \\
\hline SO3 & 0.58 & & & n/a & $\mathbf{n} / \mathbf{a}$ & $\mathbf{n} / \mathbf{a}$ & $\mathrm{n} / \mathrm{a}$ & $\mathrm{n} / \mathrm{a}$ \\
\hline Total & 100.00 & 97.06 & 2.21 & 100.86 & 96.89 & 96.52 & 95.58 & 95.46 \\
\hline
\end{tabular}


OFF-GAS ANALYSES RESULTS OF DEMONSTRATION RUN

The analyses of the off-gas constituents are still in progress at the outside vendor as the paper is being prepared for publication.

\section{CONCLUSION}

A cooperative multidisciplinary team approach to the development of waste stream vitrification processes has been shown to be effective in terms of waste glass definition, prototypical vitrification process demonstration, and analysis of the results of the vitrification process. Rapid generation of successful surrogate technology' demonstrations is possible. Direct application of the demonstrated technology package to the actual radioactive waste stream provides a sound base for the establishment of working vitrification facilities.

\section{REFERENCES}

${ }^{1}$ Kormanyos, Kenneth R. and Cox, Stephen F., "A Double Wall Allcy Construction Vitrification System for Application to Hazardous and Radioactive Wastes," Proceedings of the 1995 International Incineration Conference, pp. 517-519. 